\title{
$\beta$-Tricalcium Phosphate Interferes with the Assessment of Crystallinity in Burned Skeletal Remains
}

\author{
Giampaolo Piga (D), Ana Amarante, ${ }^{1}$ Calil Makhoul, ${ }^{1,2}$ Eugénia Cunha, ${ }^{1}$ \\ Assumpció Malgosa, ${ }^{3}$ Stefano Enzo, ${ }^{4}$ and David Gonçalves ${ }^{1,5,6}$ \\ ${ }^{1}$ Laboratory of Forensic Anthropology, Centre for Functional Ecology, Department of Life Sciences, University of Coimbra, Calçada \\ Martim de Freitas, 3000-456 Coimbra, Portugal \\ ${ }^{2}$ Unidade de I\&D "Química-Física Molecular", Department of Chemistry, University of Coimbra, 3004-535 Coimbra, Portugal \\ ${ }^{3}$ Unitat de Antropologia Biologica, Departament de Biologia Animal, Biologia Vegetal i Ecologia, Universitat Autonoma de \\ Barcelona, 08193 Bellaterra, Spain \\ ${ }^{4}$ Department of Chemistry and Pharmacy, University of Sassari, Via Vienna 2, 07100 Sassari, Italy \\ ${ }^{5}$ Archaeosciences Laboratory, Directorate General for Cultural Heritage and LARC/CIBIO/InBIO, Rua da Bica do Marquês 2, \\ 1300-087 Lisboa, Portugal \\ ${ }^{6}$ Research Centre for Anthropology and Health (CIAS), Department of Life Sciences, University of Coimbra, Calçada Martim Freitas, \\ 3000-456 Coimbra, Portugal
}

Correspondence should be addressed to Giampaolo Piga; kemiomara@yahoo.it

Received 29 January 2018; Accepted 26 March 2018; Published 2 May 2018

Academic Editor: Luciano Bachmann

Copyright $\odot 2018$ Giampaolo Piga et al. This is an open access article distributed under the Creative Commons Attribution License, which permits unrestricted use, distribution, and reproduction in any medium, provided the original work is properly cited.

\begin{abstract}
The analysis of burned remains is a highly complex process, and a better insight can be gained with advanced technologies. The main goal of this paper is to apply X-ray diffraction, partially supported by infrared attenuated total reflectance spectroscopy to determine changes in burned human bones and teeth in terms of mineral phase transformations. Samples of 36 bones and 12 teeth were heated at $1050^{\circ} \mathrm{C}$ and afterwards subjected to XRD and ATR-IR. The crystallinity index was calculated for every sample. A quantitative evaluation of phases was documented by using the Rietveld approach. In addition to bioapatite, the following mineralogical phases were found in the bone: $\beta$-tricalcium phosphate $\left(\beta\right.$-TCP) $\left(\mathrm{Ca}_{3}\left(\mathrm{PO}_{4}\right)_{2}\right)$, lime $(\mathrm{CaO})$, portlandite $\left(\mathrm{Ca}(\mathrm{OH})_{2}\right)$, calcite $\left(\mathrm{CaCO}_{3}\right)$, and buchwaldite $\left(\mathrm{NaCaPO}_{4}\right)$. In the case of bone, besides bioapatite, only the first two mineralogical phases and magnesium oxide were present. We also observed that the formation of $\beta$-TCP affects the phosphate peaks used for CI calculation. Therefore, caution is needed when its occurrence and evaluation are carried out. This is an important warning for tracking heat-induced changes in human bone, in terms of physicochemical properties related to structure, which is expected to impact in forensic, bioanthropological, and archaeological contexts.
\end{abstract}

\section{Introduction}

Forensic anthropologists and bioarchaeologists are frequently confronted with the need to study and interpret burned bones. Their importance for forensic investigations and for the study of past populations is unquestionable (e.g., the $9 / 11$ attacks) [1-7].

For example, burned bones from forensic settings include those of fire victims resulting from, among others, vehicle accidents, mass disasters, and house fires. In addition to accidents, in homicides, the victim's body may be purposely burned by the perpetrator in an attempt to destroy it, thus obstructing the investigation. Indeed, the effect of high temperatures on the human body can undermine and drastically complicate the bioanthropologists' examination. Regardless of the context, one of the key factors for the correct interpretation of the remains and the reconstruction of the incidents leading to burning is the estimation of the maximum exposure temperature [8-10]. Micro- and ultrastructural analyses on burned skeletal remains are crucial for obtaining a reliable estimation of maximum burning temperature [11]. While macroscopic alterations (e.g., surface colour) can be used to 


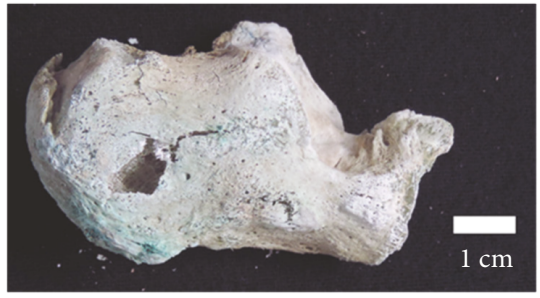

(a)

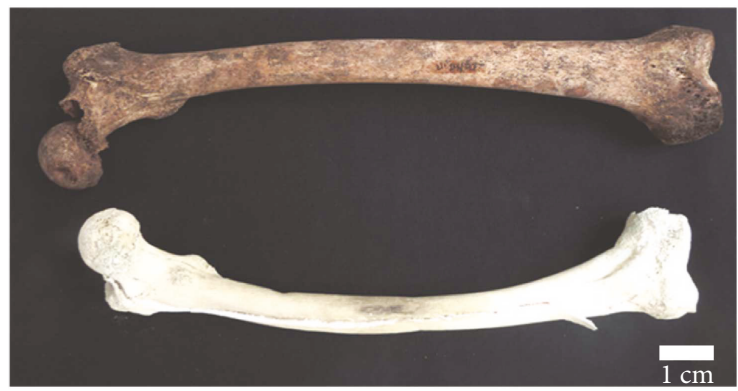

(c)

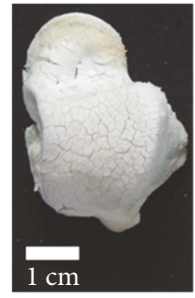

(b)

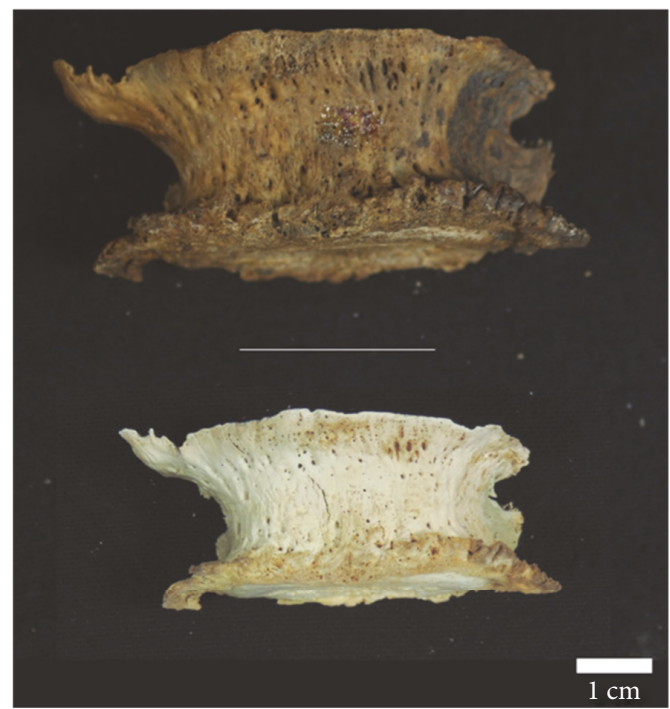

(d)

FIGURE 1: Four examples of burned bones used in this study: (a) CC/NI/16, left calcaneus; (b) CC/NI/17, left talus; (c) CC/NI/16, comparison between unburned right femur and burned left femur; and (d) CC/NI/18, comparison between unburned and burned thoracic vertebra. The burned vertebra was affected by heat-induced shrinkage, thus explaining its substantial smaller size in comparison to the unburned vertebra.

deduce an approximate temperature range [12-15], the investigation of the micro- and ultrastructural alterations of skeletal hard tissue exposed to high temperatures has proven to be crucial to get a reliable estimation of maximum temperature $[8,9,13,16-23]$. The bone which has been thermally altered shows an increase in crystallinity, exhibiting larger crystals and lower lattice strains [8, 9, 13, 16-31].

The analysis of burned remains is a highly complex process, and with new technologies available, a better insight can be gained. X-ray diffraction (XRD) often combined with Fourier-transform infrared spectroscopy attenuated total reflectance (ATR-IR) techniques is actually widely used to obtain primary material information in forensic and archaeological fields, such as the accuracy of temperature determination and the study of crystallinity [10].

The crystallinity index (CI), frequently reported in literature and quantified by ATR-IR or XRD, gives precious information about the mean changes in hydroxyapatite (HA) crystal size and microscopic structural order of tissues [32-39].

Recently improved FT-IR approaches and statistical methods for the comparability of CI results have been established [40]. However, the CI does not characterize individual crystal features (e.g., size or morphology) and may fail to describe adequately the complexity and heterogeneity of heat-induced processes [41]. In fact, when bioapatite is subjected to a strong thermal treatment, we can find also a multiphase condition for the resultant product due to the transformation of a part of HA to the $\beta$-tricalcium phosphate $(\beta$-TCP $)$ and other phases detected in different percentages among bones and teeth $[23,30,42,43]$. The presence of $\beta$ TCP as well as the presence of other mineralogical phases due to various taphonomic effects can strongly alter the calculation of the $\mathrm{CI}$ and other ratios $(\mathrm{C} / \mathrm{P}$ and $\mathrm{Am} / \mathrm{P}$ or $\mathrm{Am} / \mathrm{C})$ to a nonnegligible level [41].

That is why a multidisciplinary approach is always advisable, possibly with the combined use of various physicochemical techniques.

The aim of this work is to demonstrate that only the combined use of XRD and ATR-IR techniques can document the various reactive transformations of the apatite phase. This is done by analyzing three experimentally burned human skeletons as well as 12 teeth at $1050^{\circ} \mathrm{C}$ for one hour of residence.

\section{Materials and Methods}

The human bone samples were taken from three different unidentified skeletons, previously inhumed at the Capuchos cemetery (Santarém, Portugal) for a minimum of three years and afterwards donated to the University of Coimbra. They have the same provenance as the unclaimed skeletons of the 21 st century identified skeletal collection housed at the 
TABLE 1: List of the XRD phase investigation of the three modern human individuals, according to the Rietveld analysis. The uncertainty for the phase amount is calculated on the basis of statistical assumptions on the residual behaviour but generally holds about $10 \%$ of its value when the fit is carried out correctly. The value for the mostly used agreement factor $R_{\mathrm{wp}}$ (which is a test for the goodness of the fit) in the refinement stage is also reported in the latter column. The average crystallite size of the hydroxyapatite mineral phase $\left(1 \AA=10^{-10} \mathrm{~m}\right)$ and CI from ATR-IR analysis have also been reported.

\begin{tabular}{|c|c|c|c|c|c|}
\hline Individual code & Bone sample & Crystallographic phases (wt\%) & $\begin{array}{c}\text { Bioapatite average } \\
\text { Crystallite size/( }( \pm)( \pm 10 \%)\end{array}$ & $R_{\mathrm{wp}}(\%)$ & $\mathrm{CI}$ \\
\hline CCNI16 & Left femur proximal & $\begin{array}{c}\text { Bioapatite } 89 \\
\left(\mathrm{Ca}(\mathrm{OH})_{2}\right) 9 \\
(\mathrm{CaO}) 2\end{array}$ & 1602 & 7.8 & 4.73 \\
\hline CCNI16 & Left femur distal & $\begin{array}{c}\text { Bioapatite } 92 \\
\left(\mathrm{Ca}(\mathrm{OH})_{2}\right) 3 \\
(\mathrm{CaO}) 3 \\
\left(\mathrm{CaCO}_{3}\right) 1\end{array}$ & 2200 & 8.9 & 5.30 \\
\hline CCNI16 & Left tibia proximal & $\begin{array}{c}\text { Bioapatite } 94 \\
\left(\mathrm{Ca}(\mathrm{OH})_{2}\right) 3 \\
(\mathrm{CaO}) 3\end{array}$ & 2027 & 8.98 & 5.17 \\
\hline CCNI16 & Left tibia distal & $\begin{array}{l}\text { Bioapatite } 89 \\
\qquad(\mathrm{CaO}) 5 \\
\left(\mathrm{CaCO}_{3}\right) 2 \\
\left(\mathrm{Ca}(\mathrm{OH})_{2}\right) 2 \\
\left(\mathrm{NaCaPO}_{4}\right) 2\end{array}$ & 2100 & 9.00 & 4.83 \\
\hline CCNI16 & Left humerus proximal & $\begin{array}{c}\text { Bioapatite } 86 \\
\left(\mathrm{Ca}(\mathrm{OH})_{2}\right) 9 \\
(\mathrm{CaO}) 5\end{array}$ & 2057 & 8.00 & 5.84 \\
\hline CCNI16 & Left humerus distal & $\begin{array}{c}\text { Bioapatite } 84 \\
\left(\mathrm{Ca}(\mathrm{OH})_{2}\right) 10 \\
\left(\mathrm{CaCO}_{3}\right) 4 \\
(\mathrm{CaO})_{2} 2\end{array}$ & 1800 & 8.4 & 5.85 \\
\hline CCNI16 & Left ulna proximal & $\begin{array}{c}\text { Bioapatite } 84 \\
\left(\mathrm{Ca}(\mathrm{OH})_{2}\right) 12 \\
(\mathrm{CaO})^{4}\end{array}$ & 1993 & 8.02 & 5.20 \\
\hline CCNI16 & Left ulna distal & $\begin{array}{l}\text { Bioapatite } 94 \\
\qquad(\mathrm{CaO}) 3 \\
\left(\mathrm{CaCO}_{3}\right) 2 \\
\left(\mathrm{Ca}(\mathrm{OH})_{2}\right) 1\end{array}$ & 1800 & 9.6 & 4.40 \\
\hline CCNI16 & Left radius proximal & $\begin{array}{c}\text { Bioapatite } 89 \\
\left(\mathrm{Ca}(\mathrm{OH})_{2}\right) 8 \\
(\mathrm{CaO}) 3\end{array}$ & 2031 & 8.6 & 5.76 \\
\hline CCNI16 & Left radius distal & $\begin{array}{c}\text { Bioapatite } 92 \\
\qquad(\mathrm{CaO}) 3 \\
\left(\mathrm{CaCO}_{3}\right) 1\end{array}$ & 1970 & 9.4 & 4.91 \\
\hline CCNI16 & Left rib 9th anterior distal & $\begin{array}{l}\text { Bioapatite } 98 \\
\quad(\mathrm{CaO}) 2\end{array}$ & 1970 & 9.57 & 5.30 \\
\hline CCNI16 & Left rib 9th anterior proximal & $\begin{array}{c}\text { Bioapatite } 96 \\
(\mathrm{CaO}) 3 \\
\left(\mathrm{CaCO}_{3}\right) 1\end{array}$ & 1850 & 9.00 & 5.17 \\
\hline CCNI16 & Left rib 10th anterior distal & $\begin{array}{c}\text { Bioapatite } 98 \\
\qquad(\mathrm{CaO}) 1 \\
\left(\mathrm{CaCO}_{3}\right) 1\end{array}$ & 1900 & 9.00 & 4.74 \\
\hline CCNI16 & Left rib 10th anterior proximal & Bioapatite 99 & 1540 & 7.8 & 4.70 \\
\hline
\end{tabular}


TABle 1: Continued.

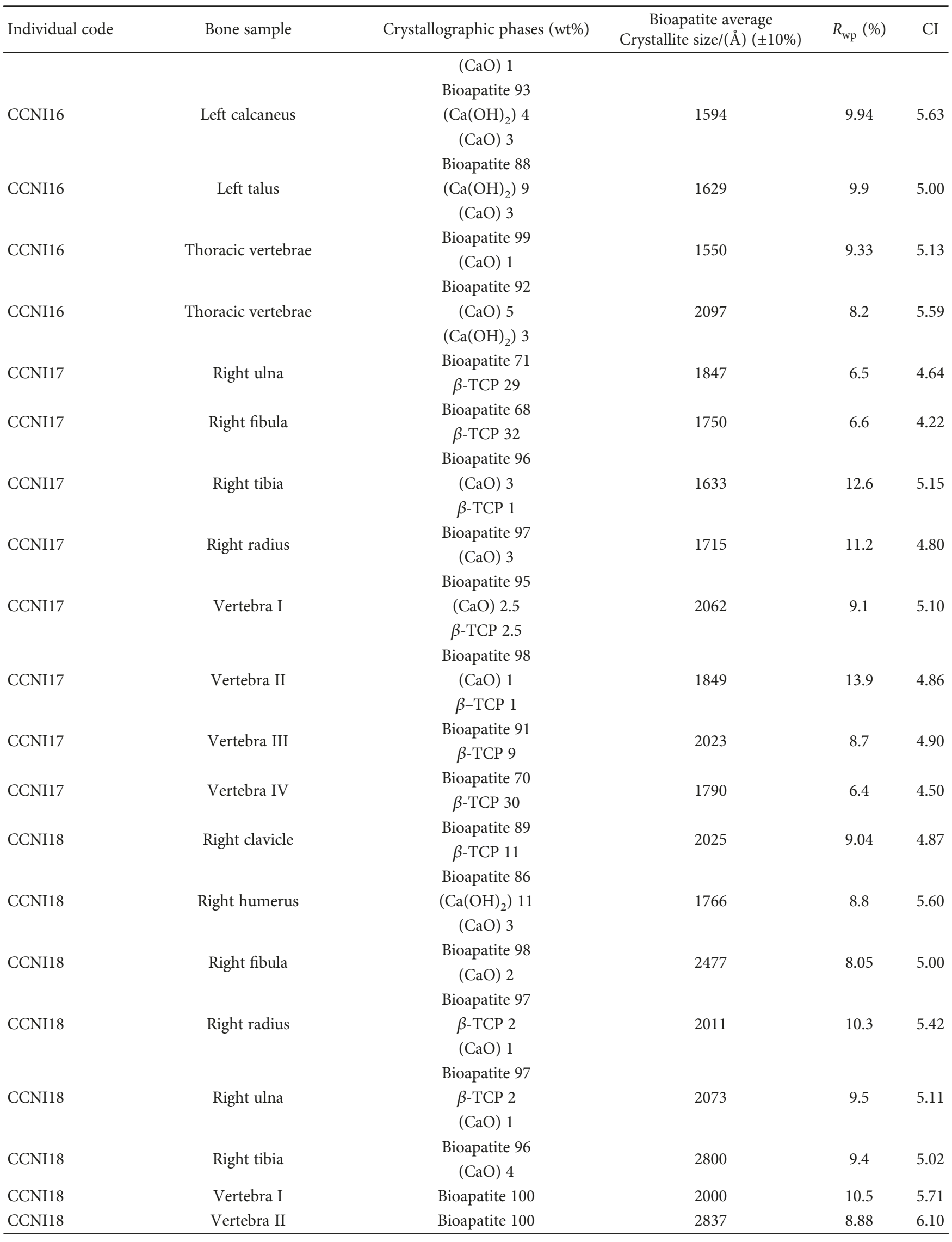


TABLe 1: Continued.

\begin{tabular}{|c|c|c|c|c|c|}
\hline Individual code & Bone sample & Crystallographic phases (wt\%) & $\begin{array}{c}\text { Bioapatite average } \\
\text { Crystallite size/(A) }( \pm 10 \%)\end{array}$ & $R_{\mathrm{wp}}(\%)$ & $\mathrm{CI}$ \\
\hline CCNI18 & Vertebra III & Bioapatite 100 & 1780 & 9.5 & 5.50 \\
\hline CCNI18 & Vertebra IV & Bioapatite 100 & 1907 & 9.06 & 5.43 \\
\hline
\end{tabular}

Laboratory of Forensic Anthropology of the University of Coimbra (Portugal) [44]. The three skeletons (CC/NI/16, $\mathrm{CC} / \mathrm{NI} / 17$, and $\mathrm{CC} / \mathrm{NI} / 18$ ) are from unidentified individuals who were nonetheless estimated to be adult females based on anthropological examinations [45].

The skeletal remains were cleaned and macerated. The most superficial region of the bones was discarded with a scalpel to avoid possible contaminated samples and only then bone powder sampling took place. Samples were then concealed in Eppendorf pellets until the XRD analysis was performed. The CC/NI/16 samples comprised the humerus, radius, ulna, femur, tibia, calcaneus, talus (see Figure 1), and ribs 9 and 10, all from the left side. Additionally, sampling of a thoracic vertebra was carried out for this skeleton. The CC/NI/17 samples comprised the right ulna, radius, tibia, and fibula as well as two thoracic and two lumbar vertebrae.

Finally, the CC/NI/18 samples were composed of the clavicle, humerus, radius, and ulna, all from the right side. Samples from one cervical, two thoracic, and one lumbar vertebra were also collected.

The 12 human molar teeth employed in this study were kindly made available from the Department of Animal Biology, Plant Biology and Ecology, Autonomous University of Barcelona (Spain).

The experimental burning of the bones from the unidentified skeletons was carried out in an electric muffle (Barracha $\mathrm{K}-3$, three-phased $14 \mathrm{~A}$ model). The bones were all subjected to gradually increasing heating from room temperature to $1050^{\circ} \mathrm{C}$, which took $240 \mathrm{~min}$ to achieve. The muffle was then allowed to cool down to room temperature. In total, 48 samples were collected for XRD and ATR-IR analyses.

The 12 molar teeth for this experiment were heat-treated with a heating rate of $20^{\circ} \mathrm{C} / \mathrm{min}$ at $1050^{\circ} \mathrm{C}$ for 60 minutes in air using a NEY muffle furnace. $0.5 \mathrm{~g}$ of each sample was ball milled in an agate jar for one minute using a SPEX Mixer/ Mill model 8000, to get enough powder for the XRD and ATR-IR analyses.

2.1. XRD Analysis. A small fraction $(190 \mathrm{mg})$ of powdered bones was deposited in a dedicated sample holder for XRD analysis with a circular cavity of $25 \mathrm{~mm}$ in diameter and $2 \mathrm{~mm}$ in depth. The XRD patterns were collected using the Bruker D2 PHASER instrument working at a power of $30 \mathrm{Kv}$ and $10 \mathrm{Ma}$ in the Bragg-Brentano vertical alignment with a $\mathrm{Cu}$-Ka tube emission $(\lambda=1.5418 \AA)$. The width of divergent and antiscatter slits was $1 \mathrm{~mm}\left(0.61^{\circ}\right)$. Primary and secondary axial Soller slits of $2.5^{\circ}$ were also mounted with a linear detector LYNXEYE with $5^{\circ}$ opening and a monochromatisation by $\mathrm{Ni}$ foil for the $\mathrm{K} \beta$ radiation. The powder patterns were collected in the angular range $9-140^{\circ}$

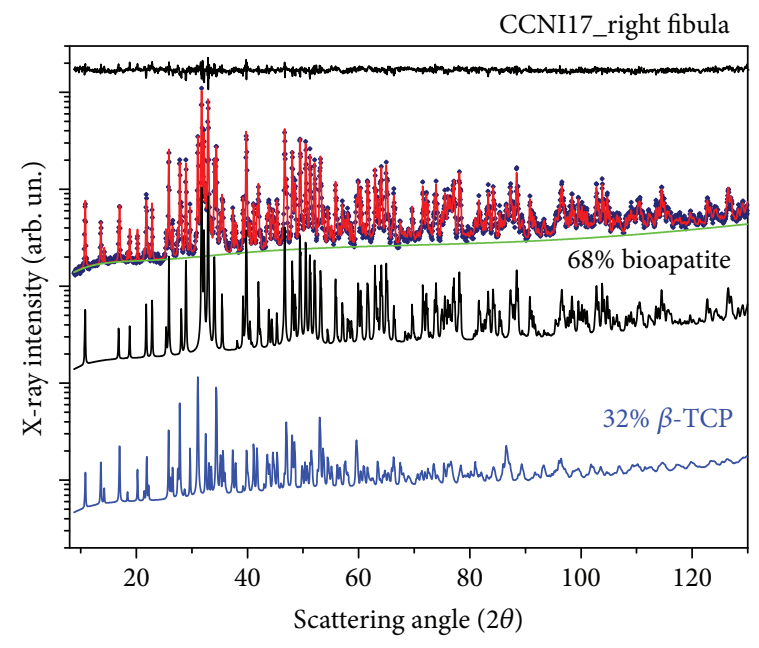

Figure 2: CC/NI/17_right fibula represents one of the rare bone specimens showing a partial transformation to $\beta$-TCP. According to Rietveld analysis, the amount of bioapatite is $68 \mathrm{wt} \%$ and $32 \mathrm{wt} \%$ belongs to $\beta$-tricalcium phosphate. The residuals are reported on the top of the graph for ease of presentation.

in $2 \theta$ with a step size of $0.05^{\circ}$. The collection time of each pattern was pursued for $47 \mathrm{~min}$.

Digitized diagrams were subjected to the analysis by the HighScore ${ }^{\circledR}$ and Match $^{\circledR}$ programs which are able to locate the peak position in the $2 \theta$ reciprocal scale. The succession of peaks is compared with data from literature based on a search-match algorithm able to recognize the phase composition. The raw data were further analysed using the Rietveld approach for quantitative evaluation of phases.

The Rietveld method $[46,47]$ is based on an iterative best-fit strategy of experimental data. We have made use of the MAUD (Material Analysis Using Diffraction) program which simulates the pattern by incorporating the instrument function and convolving the crystallographic model based on the knowledge of chemical composition and space group with selected texture and microstructure models [48]. The program permits a selection of variables for the least squares minimization such as lattice parameters of the unit cell, atomic positions, temperature factors, occupancy of the sites, an/isotropic size, and strain broadening.

The success of the procedure is generally evaluated throughout a combination of integrated agreement factors ( $R_{\mathrm{wp}}$ is the most considered) and distribution of residuals [47].

2.2. ATR Analysis. FT-IR spectra were collected in ATR mode with a Bruker Alpha Platinum-ATR interferometer in terms of absorbance versus wavenumber $v$ in the range $370-4000 \mathrm{~cm}^{-1}$, with a resolution of $4 \mathrm{~cm}^{-1}$. Each spectrum was obtained by averaging 512 interferograms. The loose 
TABLE 2: List of structure and microstructure parameters of bioapatite structure in teeth from phase analysis by XRD and the associated ATRIR CI.

\begin{tabular}{|c|c|c|c|c|c|}
\hline Sample code & Part of the body & Crystallographic phases (wt\%) & 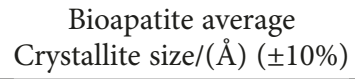 & $R_{\mathrm{wp}}(\%)$ & $\mathrm{CI}$ \\
\hline T1 & Upper left 1st molar & $\begin{array}{c}\text { Bioapatite } 55 \\
\beta \text {-TCP } 44 \\
(\mathrm{MgO}) 1\end{array}$ & 1375 & 10.45 & 3.24 \\
\hline $\mathrm{T} 2$ & Upper right 1st molar & $\begin{array}{c}\text { Bioapatite } 97 \\
\beta \text {-TCP } 2 \\
(\mathrm{CaO}) 1\end{array}$ & 1709 & 9.36 & 4.37 \\
\hline T3 & Lower left 3rd molar & $\begin{array}{c}\text { Bioapatite } 57 \\
\beta \text {-TCP } 42 \\
(\mathrm{MgO}) 1\end{array}$ & 1456 & 7.22 & 3.42 \\
\hline $\mathrm{T} 4$ & Upper left 3rd molar & $\begin{array}{c}\text { Bioapatite } 74 \\
\beta \text {-TCP } 25 \\
(\mathrm{MgO}) 1\end{array}$ & 1631 & 8.22 & 3.42 \\
\hline T5 & Upper left 2nd molar & $\begin{array}{c}\text { Bioapatite } 90 \\
\beta \text {-TCP } 8 \\
(\mathrm{CaO}) 2\end{array}$ & 1830 & 10.39 & 4.39 \\
\hline T6 & Lower right 2nd molar & $\begin{array}{c}\text { Bioapatite } 87 \\
\beta \text {-TCP } 11 \\
(\mathrm{CaO}) 2\end{array}$ & 1870 & 7.57 & 3.81 \\
\hline T7 & Upper left 1st molar & $\begin{array}{c}\text { Bioapatite } 89 \\
\beta \text {-TCP } 8 \\
(\mathrm{MgO}) 3\end{array}$ & 1822 & 10.60 & 4.29 \\
\hline T8 & Lower left 3rd molar & $\begin{array}{c}\text { Bioapatite } 78 \\
\beta \text {-TCP } 22\end{array}$ & 1613 & 10.07 & 3.57 \\
\hline T9 & Upper right 3rd molar & $\begin{array}{c}\text { Bioapatite } 93 \\
\beta \text {-ТСР } 7\end{array}$ & 1580 & 8.6 & 3.70 \\
\hline $\mathrm{T} 10$ & Lower right 1st molar & $\begin{array}{c}\text { Bioapatite } 67 \\
\beta \text {-TCP } 33\end{array}$ & 1740 & 11.00 & 3.51 \\
\hline $\mathrm{T} 11$ & Upper left 1st molar & $\begin{array}{c}\text { Bioapatite } 90 \\
\beta \text {-TCP } 10\end{array}$ & 1900 & 7.6 & 3.61 \\
\hline $\mathrm{T} 12$ & Lower left 1st molar & $\begin{array}{c}\text { Bioapatite } 96 \\
(\mathrm{CaO}) 4\end{array}$ & 1900 & 7.7 & 4.89 \\
\hline
\end{tabular}

powder was dispersed inside a hole cavity of spheroidal shape with its surface aligned to the plate defining it.

2.3. Crystallinity Index. The crystallinity index adopted here is the same as has been used in the majority of archaeological applications. The absorption bands at 605 and $565 \mathrm{~cm}^{-1}$ were used following baseline correction, and the heights of these absorptions peaks were summed and then divided by the height of the minimum between them [32].

\section{Results}

Thermally treated bones showed a very interesting variability. On a total of 48 samples burned in a muffle at $1050^{\circ} \mathrm{C}$ for 2 hour of residence, the following mineralogical phases were found in addition to bioapatite, namely, $\beta$-tricalcium phosphate $(\beta-\mathrm{TCP})\left(\mathrm{Ca}_{3}\left(\mathrm{PO}_{4}\right)_{2}\right)$, portlandite
$\left(\mathrm{Ca}(\mathrm{OH})_{2}\right)$, calcite $\left(\mathrm{CaCO}_{3}\right)$, lime $(\mathrm{CaO})$, and buchwaldite $\left(\mathrm{NaCaPO}_{4}\right)$ (see Table 1 ).

In detail, portlandite was found in 13 specimens (weight fraction range from 2 to $12 \mathrm{wt} \%), \beta$-TCP in 10 specimens (from 1 to $32 \mathrm{wt} \%$ ), lime in 27 specimens (from 1 to $5 \mathrm{wt} \%$ ), calcite in 7 specimens (from 1 to $4 \mathrm{wt} \%$ ), and buchwaldite in 1 case $(2 \mathrm{wt} \%)$. Only in 4 cases, bones have remained unaltered, bioapatite $100 \%$ (CC/NI/18 individual), apart from the microstructure features assessed from peak sharpening and the organic component, which is expected to be removed from the bone with the thermal treatment carried out.

The average crystallite size of the examined bioapatite varies from a lower value of $1540 \AA$ (CC/NI/16_left rib 10 anterior proximal) to an upper value of $2837 \AA$ (CC/NI/ 18 _vertebra II) (mean $=1950 \AA)$. The crystallinity index varies from a lower value of 6.10 (CC/NI/18_vertebra II) to an upper value of $4.22(\mathrm{CC} / \mathrm{NI} / 17$ right fibula $)($ mean $=5.14)$. 


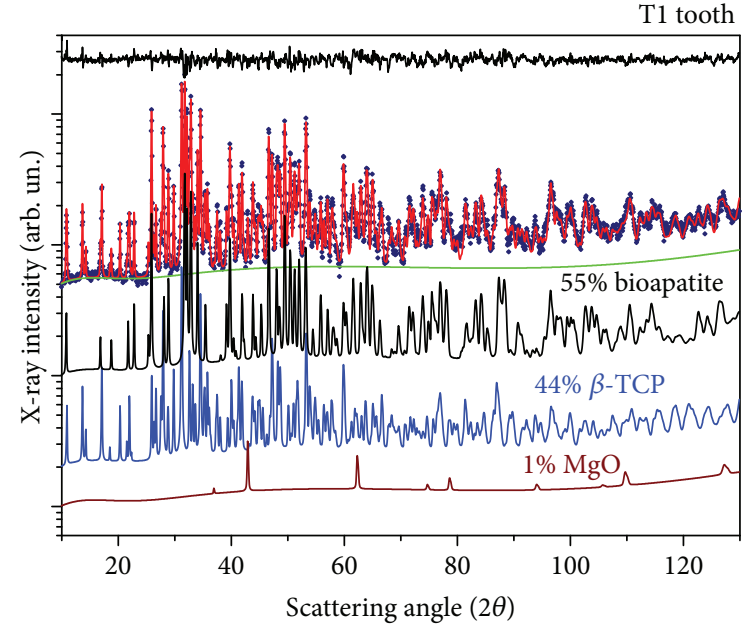

FIgURE 3: The XRD pattern of T1 tooth heated up to $1050^{\circ} \mathrm{C}$ for 1 hour. The phase analysis suggests that the material is a mixture of bioapatite $(55 \mathrm{wt} \%)$ and $\beta$-TCP $\left(\mathrm{Ca}_{3}\left(\mathrm{PO}_{4}\right)_{2}\right)$ (44.0 wt\%), with a minor contribution of $\mathrm{MgO}$.

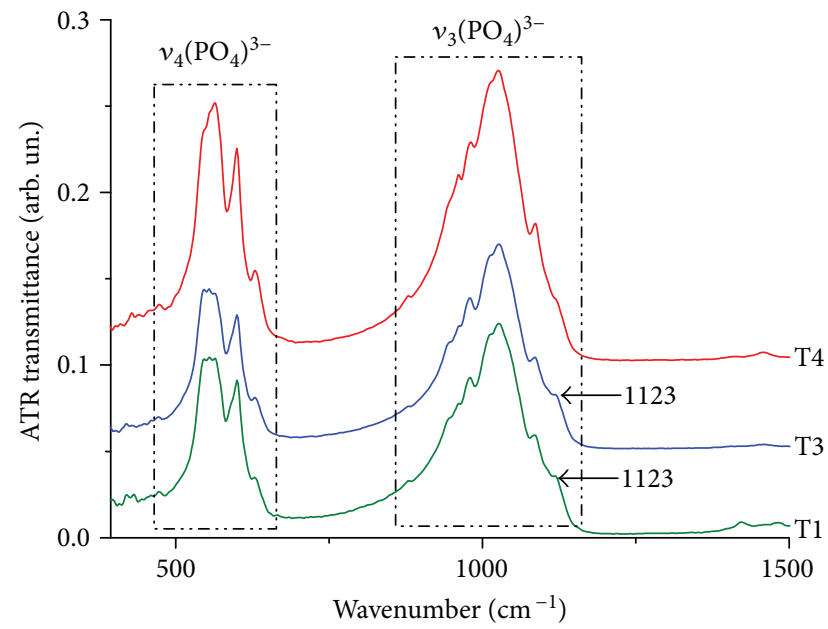

FIgURE 4: ATR-IR spectra of three human teeth heated at $1050^{\circ} \mathrm{C}$ that are particularly noteworthy because they present a significant amount of $\beta$-TCP (from bottom to top, T1 $=44 \mathrm{wt} \%$, T3 $=42 \mathrm{wt} \%$, and $\mathrm{T} 4=25 \mathrm{wt} \%$, resp.) detected with XRD. The deformation of the $v_{4}$ band is observable, as well as the presence of an additional peak at $1123 \mathrm{~cm}^{-1}$ (in $\mathrm{T} 1$ and $\mathrm{T} 2$ specimens) due to the presence of $\beta$-TCP.

An emblematic case is represented by the sample CC/NI/ 17_right fibula, in which the bioapatite after the heat treatment at $1050^{\circ} \mathrm{C}$ has partially transformed into $\beta$-TCP. The Rietveld analysis is reported in Figure 2. The experiment (data points) was fitted satisfactorily $\left(R_{\mathrm{wp}}=6.6 \%\right)$ with the full line after including structure information from the mineral bioapatite (68.0 wt $\%)$ and $\beta$-TCP (32.0 wt\%).

As for the teeth, only three mineralogical phases were detected in addition to bioapatite: $\beta$-TCP in 11 specimens (from 2 to $44 \mathrm{wt} \%$ ), lime in 4 specimens (from 1 to $4 \mathrm{wt} \%$ ), and magnesium oxide $(\mathrm{MgO})$ in 4 specimens (from 1 to 3 wt\%) (see Table 2).
The teeth have a lower crystallinity compared to the bones; in fact, the average crystallite size varies from a lower value of $1375 \AA$ (T1 tooth) to an upper value of $1900 \AA$ (T11 tooth) $($ mean $=1702 \AA)$. The crystallinity index varies from a lower value of 3.24 (T1 tooth) to an upper value of 4.89 (T12 tooth) $($ mean $=3.85)$.

Figure 3 represents an extreme case ( $\mathrm{T} 1$ sample), in which the analysis of the correspondent XRD pattern has established the presence of the $44 \% \beta$-TCP phase for such specimen.

Figure 4 shows the ATR-IR spectra of three burned teeth (from bottom to top: T1, T3, and T4, resp.). The spectra are reported in the wavenumber $v$ ranging from 400 to $1500 \mathrm{~cm}^{-1}$.

It is possible to recognize two main groups of bands in the range of $500-700 \mathrm{~cm}^{-1}$ and $1000-1200 \mathrm{~cm}^{-1}$, which are generally assigned to the energy mode $v_{4}$ of phosphate groups and $v_{3}$ of phosphate groups, respectively. An additional peak at about $1123 \mathrm{~cm}^{-1}$ (see Figure 3) in T1 and T3 samples as indicated by arrows is attributable to $\beta$-TCP.

Particularly, the $v_{4}$ band of the phosphates present in the ATR-IR spectrum can provide a variety of supporting information to XRD analysis, due to numerous deformations and displacements of the band shape and to the CI calculation.

In detail, Figure 5 highlights the band structure of $v_{4}$ phosphate groups in the range $500-700 \mathrm{~cm}^{-1}$ of representative samples; Figure 5(a) shows the conventional pattern of CC/NI/18_vertebra II sample in which the bioapatite phase remained unchanged after the experimental heating $(\mathrm{HA}=100 \%)$, as far as its crystal structure is concerned; the presence and the intensity of the shoulder at about $629 \mathrm{~cm}^{-1}$ indicate the occurrence of high thermal treatments [49]. The larger average crystallite size $(2837 \AA)$ detected by XRD is coherent with the high value of CI (6.10).

Figure $5(\mathrm{~b})$ documents the case (T4 tooth) in which the presence of $\beta$-TCP is rather substantial; in fact, the $v_{4}$ band begins to slightly overlap with the $v_{4}$ band of bioapatite (evidenced by the additional peaks at 456 and $555 \mathrm{~cm}^{-1}$ indicated by arrows).

Figure 5(c) represents the extreme case of T1 tooth when the presence of $\beta$-TCP is massive (44\%); in fact, the $v_{4}$ band appears strongly deformed due to the complete overlap with the $v_{4}$ band of bioapatite (see the deformation of the peak at $555 \mathrm{~cm}^{-1}$ with the presence of two further peaks at 546 and $563 \mathrm{~cm}^{-1}$, resp.). In such cases, the CI calculation is problematic and the value is unusually low when compared to that of other burned bone samples.

\section{Discussion and Conclusive Remarks}

The occurrence of $\beta$-TCP can follow from a chemical reaction according to which $\mathrm{Ca}_{10}\left(\mathrm{PO}_{4}\right)_{6}(\mathrm{OH})_{2}$ is subjected at high temperature, giving $3\left(\mathrm{Ca}_{3}\left(\mathrm{PO}_{4}\right)_{2}\right)+\mathrm{CaO}$ and water vapour $\mathrm{H}_{2} \mathrm{O}$.

$$
\left[2 \mathrm{Ca}_{5}\left(\mathrm{PO}_{4}\right)_{3} \mathrm{OH} \rightarrow 3 \mathrm{Ca}_{3}\left(\mathrm{PO}_{4}\right)_{2}+\mathrm{CaO}+\mathrm{H}_{2} \mathrm{O}\right]
$$

If water $\left(\mathrm{H}_{2} \mathrm{O}\right)$ evaporates completely, we observe the presence of $\mathrm{CaO}$; alternatively, incomplete evaporation develops into $\mathrm{Ca}(\mathrm{OH})_{2}$. It depends on the speed of cooling after the burning process. 


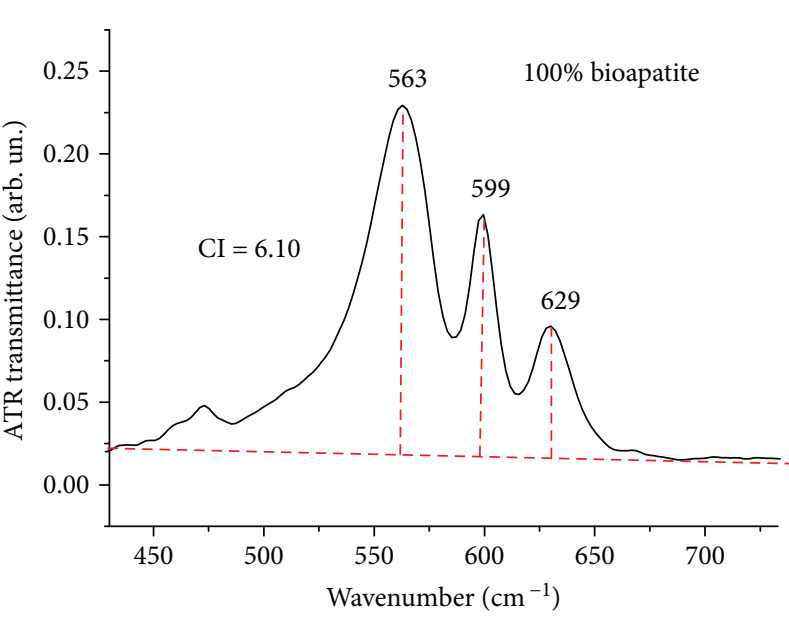

(a) CC/NI/18_vertebra II

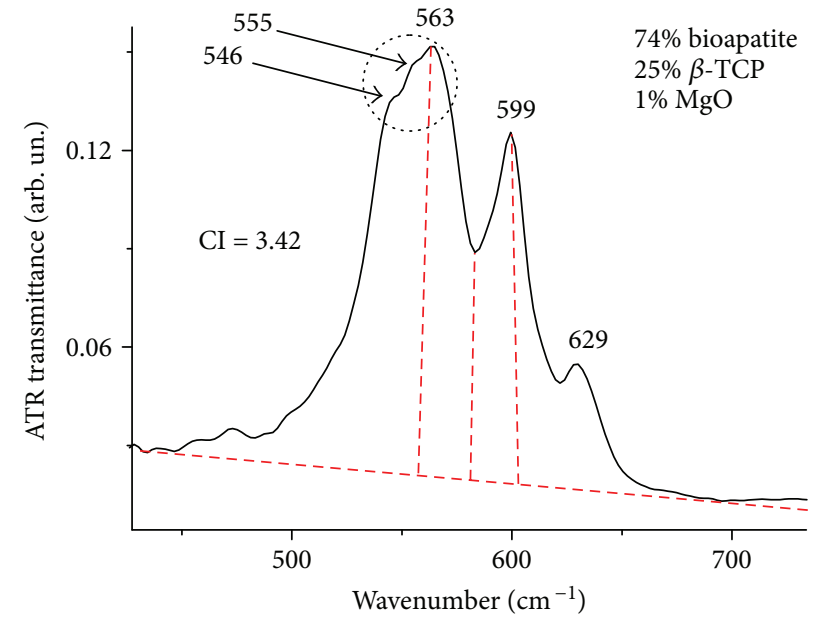

(b) T4 tooth

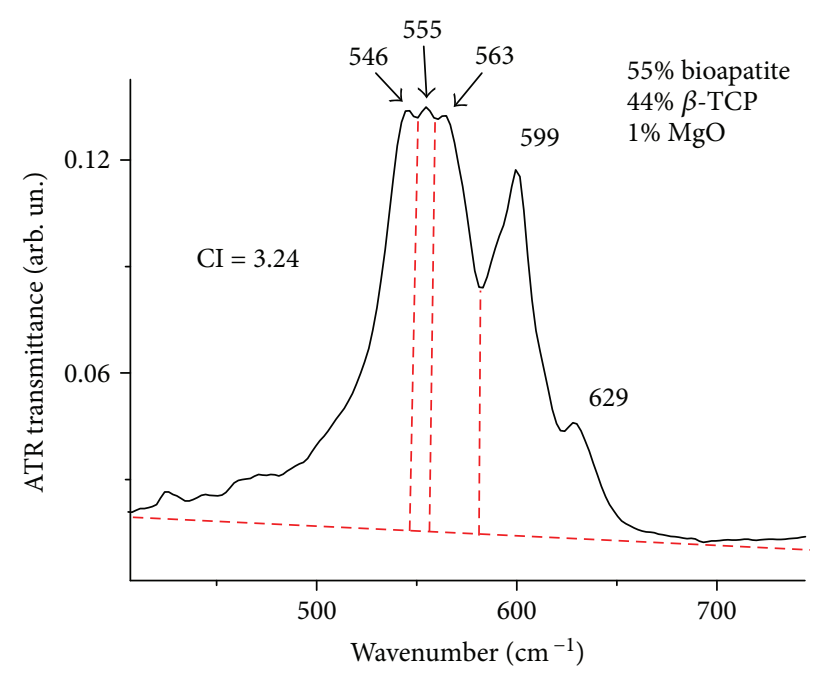

(c) T1 tooth

FIGURE 5: A detailed comparison of different FT-IR curves collected for three different bioapatite specimens: (a) CC/NI/18_vertebra II, (b) T4 tooth, and (c) T1 tooth with the corresponding XRD Rietveld phase evaluation. The distortions of ATR-IR $v_{4}$ phosphate band with respect to the conventional expected behavior are strictly related to the amount of the $\beta$-TCP phase which was stimulated by the high-temperature treatment. Particularly, when the presence of $\beta$-TCP is massive $(\geq 20 \%)$, the $v_{4}$ band appears strongly deformed due to the overlap with the $v_{4}$ band of bioapatite (see the deformation of the peak at $563 \mathrm{~cm}^{-1}$ ), and also, the CI calculation is problematic.

Recent studies [50] have attempted to clarify the transformation of a Ca-deficient synthetic apatite to $\beta$-TCP. Upon heating (calcining) to $710 \pm 740^{\circ} \mathrm{C}$, the Ca-deficient apatite will transform to the low-temperature polymorph of $\beta$-TCP, with the loss of water as described by

$$
\left[\mathrm{Ca}_{9}\left(\mathrm{HPO}_{4}\right)\left(\mathrm{PO}_{4}\right)_{5}(\mathrm{OH}) \rightarrow 3 \mathrm{Ca}_{3}\left(\mathrm{PO}_{4}\right)_{2}+\mathrm{H}_{2} \mathrm{O}\right]
$$

where $\mathrm{CaO}$ is missing with respect to the $2\left(\mathrm{Ca}_{5}\left(\mathrm{PO}_{4}\right)_{3}(\mathrm{OH})\right)$ conventional formula recognized for bioapatite.

$\mathrm{NaCaPO}_{4}$ and $\mathrm{MgO}$ are also observed in very small quantities probably as a consequence of impurities in the starting bone material.

The presence of $\beta$-TCP phase from bones appears to be sporadic and seems to occur only at high temperatures, around $1100^{\circ} \mathrm{C}$ [43]. Conversely, in our previous work, we observed a more systematic occurrence of $\beta$-TCP in teeth specimens at temperatures as low as $750^{\circ} \mathrm{C}[41]$.

The reason why $\beta$-TCP appears in teeth at a relatively moderate temperature in comparison to bones is still obscure; it may be related to the fact that bones and teeth have different compositions and histologies, and further studies need to be addressed by acquiring information about chemical species and following the crystal structure parameters.

Our results demonstrate that the use of the CI for bioanthropological inferences such as those related to temperature estimation $[8,9,35,39]$ and to the determination of bone quality and preservation $[32,33]$ is not a straightforward procedure. Since the generation of $\beta$-TCP can affect the phosphate peaks located at the wavelength of interest for CI calculation, one should be especially careful whenever such peaks present anomalous shapes. 
This paper alerts to this problem since implications for fields that incorporate bone analyses may be major.

\section{Conflicts of Interest}

The authors declare that there is no conflict of interests regarding the publication of this paper.

\section{Acknowledgments}

This work was partially supported by the Autonomous Region of Sardinia (LR3/2008-R.Cervelli and S. Politiche), with the research project titled "Archaeometric and Physico-Chemical Investigation Using a Multi-Technique Approach on Archaeological, Anthropological and Paleontological Materials from the Mediterranean area and Sardinia."

\section{References}

[1] M. Bohnert, T. Rost, and S. Pollak, "The degree of destruction of human bodies in relation to the duration of the fire," Forensic Science International, vol. 95, no. 1, pp. 11-21, 1998.

[2] S. Beckett, K. D. Rogers, and J. D. Clement, "Inter-species variation in bone mineral behavior upon heating," Journal of Forensic Sciences, vol. 56, no. 3, pp. 571-579, 2011.

[3] J. I. McKinley, "The analysis of cremated bone," in Human Osteology: in Archaeology and Forensic Science, M. Cox and S. Mays, Eds., Greenwich Medical Media Ltd, London, GB, 2000.

[4] T. J. U. Thompson, "Recent advances in the study of burned bone and their implications for forensic anthropology," Forensic Science International, vol. 146, pp. S203-S205, 2004.

[5] D. H. Ubelaker, "The forensic evaluation of burned skeletal remains: a synthesis," Forensic Science International, vol. 183, no. 1-3, pp. 1-5, 2008.

[6] D. Gonçalves, T. J. U. Thompson, and E. Cunha, "Implications of heat-induced changes in bone on the interpretation of funerary behaviour and practice," Journal of Archaeological Science, vol. 38, no. 6, pp. 1308-1313, 2011.

[7] D. Gonçalves, T. J. U. Thompson, and E. Cunha, "Estimation of the pre-burning condition of human remains in forensic contexts," International Journal of Legal Medicine., vol. 129, no. 5, pp. 1137-1143, 2014.

[8] G. Piga, A. Malgosa, T. J. U. Thompson, and S. Enzo, “A new calibration of the XRD technique for the study of archaeological burned human remains," Journal of Archaeological Science, vol. 35, no. 8, pp. 2171-2178, 2008.

[9] G. Piga, A. Malgosa, T. J. U. Thompson, and S. Enzo, "The potential of X-ray diffraction in the analysis of burned remains from forensic contexts," Journal of Forensic Sciences, vol. 54, no. 3, pp. 534-539, 2009.

[10] S. T. D. Ellingham, T. J. U. Thompson, M. Islam, and G. Taylor, "Estimating temperature exposure of burnt bone - a methodological review," Science \& Justice, vol. 55, no. 3, pp. 181-188, 2015.

[11] T. J. U. Thompson, "Heat-induced dimensional changes in bone and their consequences for forensic anthropology," Journal of Forensic Sciences, vol. 50, no. 5, pp. 1-8, 2005.

[12] P. Shipman, G. Foster, and M. Schoeninger, "Burnt bones and teeth: an experimental study of color, morphology, crystal structure and shrinkage," Journal of Archaeological Science, vol. 11, no. 4, pp. 307-325, 1984.
[13] J. Buikstra and M. Swegle, "Bone modification due to burning: experimental evidence," in Bone Modification, R. Bonnichsen and M. H. Sorg, Eds., pp. 247-258, Center for the Study of the First Americans, Orono, ME, USA, 1984.

[14] L. Bennett, “Thermal alteration of buried bone," Journal of Archaeological Science, vol. 26, no. 1, pp. 1-8, 1999.

[15] J. J. Schultz, M. W. Warren, and J. S. Krigbaum, "Analysis of human cremains: gross and chemical methods," in The Analysis of Burned Human Remains, C. W. Schmidt and S. A. Symes, Eds., pp. 75-94, Academic Press, London, 2008.

[16] J. L. Holden, J. G. Clement, and P. P. Phakey, "Age and temperature related changes to the ultrastructure and composition of human bone mineral," Journal of Bone and Mineral Research, vol. 10, no. 9, pp. 1400-1409, 1995.

[17] T. Nakano, A. Tokumura, and Y. Umakoshi, "Variation in crystallinity of hydroxyapatite and the related calcium phosphates by mechanical grinding and subsequent heat treatment," Metallugical and Materials Transactions A, vol. 33, no. 3, pp. 521-528, 2002.

[18] K. D. Rogers and P. Daniels, "An X-ray diffraction study of the effects of heat treatment on bone mineral microstructure," Biomaterials, vol. 23, no. 12, pp. 2577-2585, 2002.

[19] J. Hiller, T. J. U. Thompson, M. P. Evison, A. T. Chamberlain, and T. J. Wess, "Bone mineral change during experimental heating: an X-ray scattering investigation," Biomaterials, vol. 24, no. 28, pp. 5091-5097, 2003.

[20] S. Enzo, M. Bazzoni, V. Mazzarello, G. Piga, P. Bandiera, and P. Melis, "A study by thermal treatment and X-ray powder diffraction on burnt fragmented bones from tombs II, IV and IX belonging to the hypogeic necropolis of "Sa Figu" near Ittiri, Sassari (Sardinia, Italy)," Journal of Archaeological Science, vol. 34, no. 10, pp. 1731-1737, 2007.

[21] M. Figueiredo, A. Fernando, G. Martins, J. Freitas, F. Judas, and H. Figueiredo, "Effect of the calcination temperature on the composition and microstructure of hydroxyapatite derived from human and animal bone," Ceramics International, vol. 36, no. 8, pp. 2383-2393, 2010.

[22] S. Galeano and M. L. García-Lorenzo, "Bone mineral change during experimental calcination: an X-ray diffraction study," Journal of Forensic Sciences, vol. 59, no. 6, pp. 1602-1606, 2014.

[23] M. A. Sandholzer, T. Sui, A. M. Korsunsky, A. D. Walmsley, P. J. Lumley, and G. Landini, "X-ray scattering evaluation of ultrastructural changes in human dental tissues with thermal treatment," Journal of Forensic Sciences, vol. 59, no. 3, pp. 769-774, 2014.

[24] R. E. Taylor, P. E. Hare, and T. D. White, "Geochemical criteria for thermal alteration of bone," Journal of Archaeological Science, vol. 22, no. 1, pp. 115-119, 1995.

[25] S. Chakraborty, S. Bag, S. Pal, and A. K. Mukherjee, "Structural and microstructural characterization of bioapatites and synthetic hydroxyapatite using X-ray powder diffraction and Fourier transform infrared techniques," Journal of Applied Crystallography, vol. 39, no. 3, pp. 385-390, 2006.

[26] S. E. Etok, E. Valsami-Jones, T. J. Wess et al., "Structural and chemical changes of thermally treated bone apatite," Journal of Materials Science, vol. 42, no. 23, pp. 98079816, 2007.

[27] L. E. Munro, F. J. Longstaffe, and C. D. White, "Burning and boiling of modern deer bone: effects on crystallinity and oxygen isotope composition of bioapatite phosphate," Palaeogeography 
Palaeoclimatology Palaeoecology, vol. 249, no. 1-2, pp. 90-102, 2007.

[28] G. Piga, A. Malgosa, V. Mazzarello, P. Bandiera, P. Melis, and S. Enzo, "Anthropological and physico-chemical investigation on the burnt remains of tomb IX in the "Sa Figu" hypogeal necropolis (Sassari-Italy)-Early Bronze Age," International Journal of Osteoarcheology, vol. 18, no. 2, pp. 167-177, 2008.

[29] K. Rogers, S. Beckett, S. Kuhn, A. Chamberlain, and J. Clement, "Contrasting the crystallinity indicators of heated and diagenetically altered bone mineral," Palaeogeography Palaeoclimatology Palaeoecology, vol. 296, no. 1-2, pp. 125129, 2010.

[30] T. Sui, M. A. Sandholzer, A. J. G. Lunt et al., "In situ X-ray scattering evaluation of heat-induced ultrastructural changes in dental tissues and synthetic hydroxyapatite," Journal of the Royal Society Interface, vol. 11, no. 95, article 20130928, 2014.

[31] G. Piga, M. D. Baró, I. Golvano Escobal et al., "A structural approach in the study of bones: fossil and burnt bones at nanosize scale," Applied Physics A, vol. 122, no. 12, article 1031, 2016.

[32] S. Weiner and O. Bar-Yosef, "States of preservation of bones from prehistoric sites in the Near East: a survey," Journal of Archaeological Science, vol. 17, no. 2, pp. 187-196, 1990.

[33] T. A. Surovell and M. C. Stiner, "Standardizing infra-red measures of bone mineral crystallinity: an experimental approach," Journal of Archaeological Science, vol. 28, no. 6, pp. 633-642, 2001.

[34] M. Lebon, I. Reiche, F. Fröhlich, J.-J. Bahain, and C. Falguères, "Characterization of archaeological burnt bones: contribution of a new analytical protocol based on derivative FTIR spectroscopy and curve fitting of the $v_{1} v_{3} \mathrm{PO}_{4}$ domain," Analytical and Bioanalytical Chemistry, vol. 392, no. 7-8, pp. 1479-1488, 2008.

[35] T. J. U. Thompson, M. Gauthier, and M. Islam, “The application of a new method of Fourier transform infrared spectroscopy to the analysis of burned bone," Journal of Archaeological Science, vol. 36, no. 3, pp. 910-914, 2009.

[36] M. Lebon, I. Reiche, J.-J. Bahain et al., "New parameters for the characterization of diagenetic alterations and heat-induced changes of fossil bone mineral using Fourier transform infrared spectrometry," Journal of Archaeological Science, vol. 37, no. 9, pp. 2265-2276, 2010.

[37] K. E. Squires, T. J. U. Thompson, M. Islam, and A. Chamberlain, "The application of histomorphometry and Fourier transform infrared spectroscopy to the analysis of early Anglo-Saxon burned bone," Journal of Archaeological Science, vol. 38, no. 9, pp. 2399-2409, 2011.

[38] T. J. U. Thompson, M. Islam, K. Piduru, and A. Marcel, "An investigation into the internal and external variables acting on crystallinity index using Fourier transform infrared spectroscopy on unaltered and burned bone," Palaeogeography Palaeoclimatology Palaeoecology, vol. 299, no. 1-2, pp. 168174, 2011.

[39] S. T. D. Ellingham, T. J. U. Thompson, and M. Islam, "The effect of soft tissue on temperature estimation from burnt bone using Fourier transform infrared spectroscopy," Journal of Forensic Sciences, vol. 61, no. 1, pp. 153-159, 2015.

[40] T. J. U. Thompson, M. Islam, and M. Bonniere, “A new statistical approach for determining the crystallinity of heat-altered bone mineral from FTIR spectra," Journal of Archaeological Science, vol. 40, no. 1, pp. 416-422, 2013.
[41] G. Piga, D. Gonçalves, T. J. U. Thompson, A. Brunetti, A. Malgosa, and S. Enzo, "Understanding the crystallinity indices behavior of burned bones and teeth by ATR-IR and $\mathrm{XRD}$ in the presence of bioapatite mixed with other phosphate and carbonate phases," International Journal of Spectroscopy, vol. 2016, Article ID 4810149, 9 pages, 2016.

[42] L. D. Mkukuma, J. M. S. Skakle, I. R. Gibson, C. T. Imrie, R. M. Aspden, and D. W. L. Hukins, "Effect of the proportion of organic material in bone on thermal decomposition of bone mineral: an investigation of a variety of bones from different species using thermogravimetric analysis coupled to mass spectrometry, high-temperature X-ray diffraction, and Fourier transform infrared spectroscopy," Calcified Tissue International, vol. 75, no. 4, pp. 321-328, 2004.

[43] G. Piga, G. Solinas, T. J. U. Thompson, A. Brunetti, A. Malgosa, and S. Enzo, "Is X-ray diffraction able to distinguish between animal and human bones?," Journal of Archaeological Science, vol. 40, no. 1, pp. 778-785, 2013.

[44] M. T. Ferreira, R. Vicente, D. Navega, D. Gonçalves, F. Curate, and E. Cunha, "A new forensic collection housed at the University of Coimbra, Portugal: the 21st century identified skeletal collection," Forensic Science International, vol. 245, pp. 202.e1-202.e5, 2014.

[45] P. Murail, J. Bruzek, F. Houët, and E. Cunha, "DSP: a tool for probabilistic sex diagnosis using worldwide variability in hipbone measurements," Paru dans Bulletins et mémoires de la Société d'Anthropologie de Paris, vol. 17, no. 3-4, 2005.

[46] H. M. Rietveld, "Line profiles of neutron powder-diffraction peaks for structure refinement," Acta Crystallographica, vol. 22, no. 1, pp. 151-152, 1967.

[47] A. Young, The Rietveld Method, IUCr, Oxford Science Publications, Oxford, 1993.

[48] L. Lutterotti, "Total pattern fitting for the combined sizestrain-stress-texture determination in thin film diffraction," Nuclear Instruments and Methods in Physics Research Section $B$, vol. 268, no. 3-4, pp. 334-340, 2010.

[49] G. Piga, M. Guirguis, P. Bartoloni, A. Malgosa, and S. Enzo, “A funerary rite study of the Phoenician-Punic necropolis of Mount Sirai (Sardinia, Italy)," International Journal of Osteoarchaeology, vol. 20, pp. 144-157, 2010.

[50] I. R. Gibson, I. Rehman, S. M. Best, and W. Bonfield, "Characterization of the transformation from calcium-deficient apatite to $\beta$-tricalciumphosphate," Journal of Materials Science: Materials in Medicine, vol. 12, pp. 799-804, 2000. 

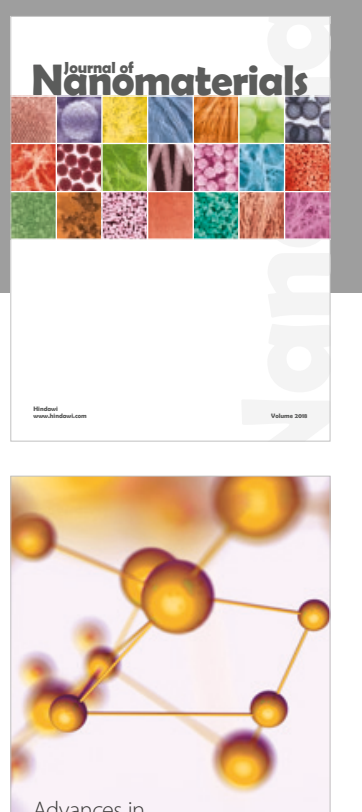

Physical Chemistry
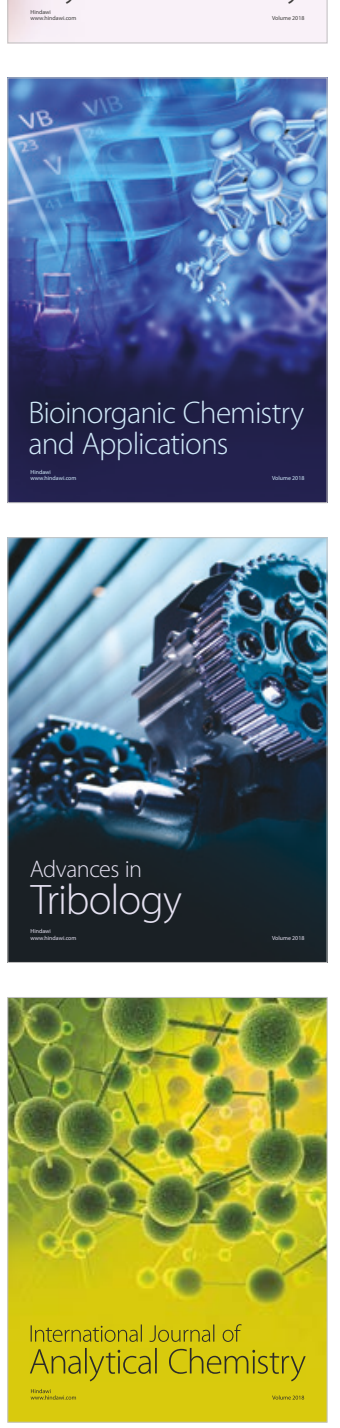

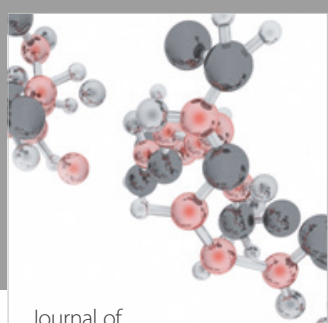

Analytical Methods

in Chemistry

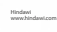

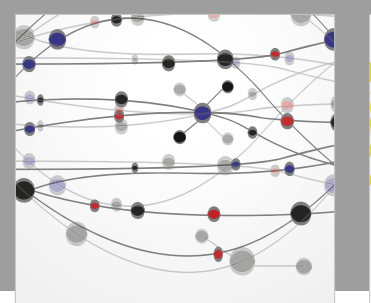

The Scientific World Journal

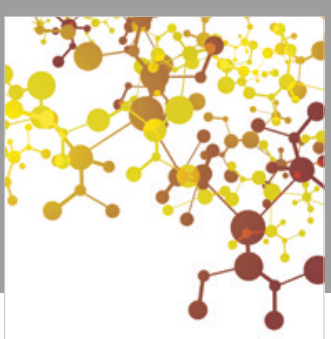

Journal of

Applied Chemistry
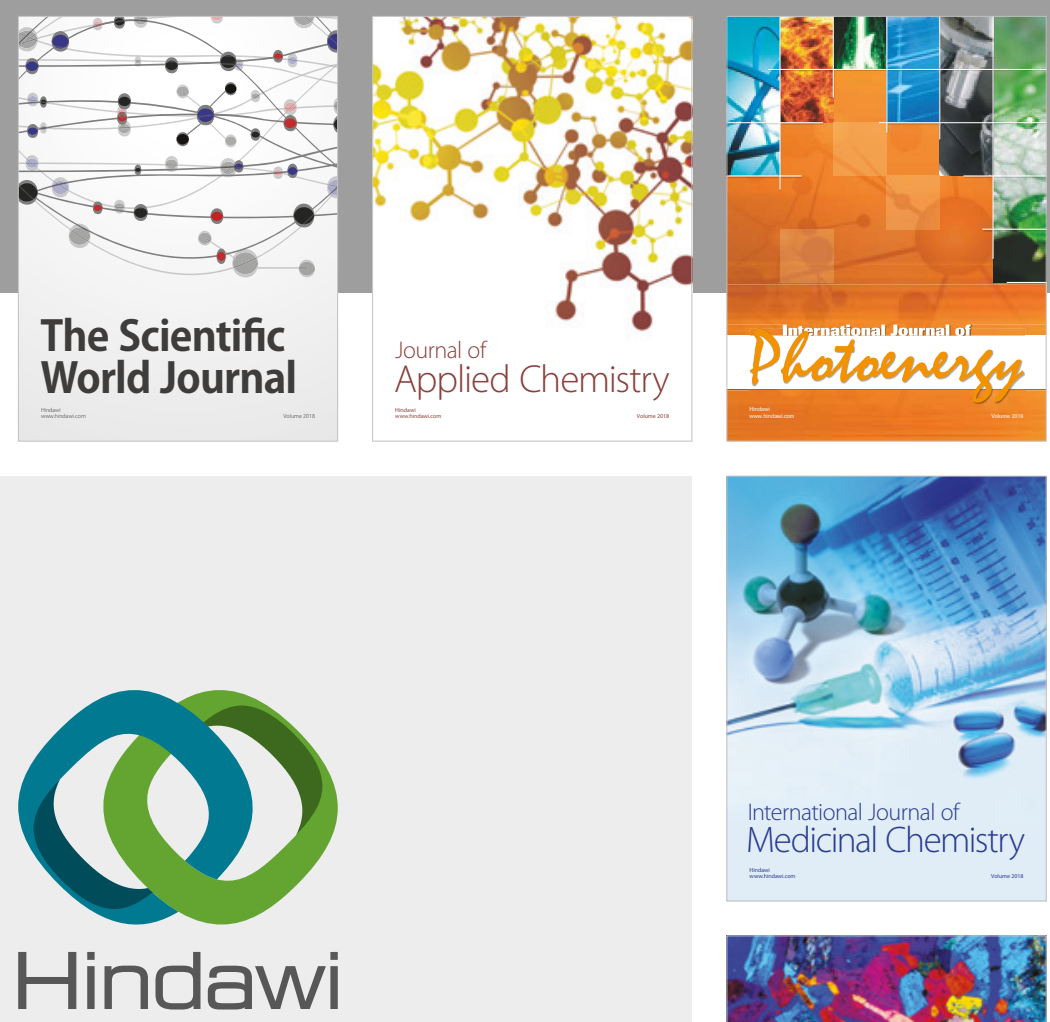

Submit your manuscripts at

www.hindawi.com
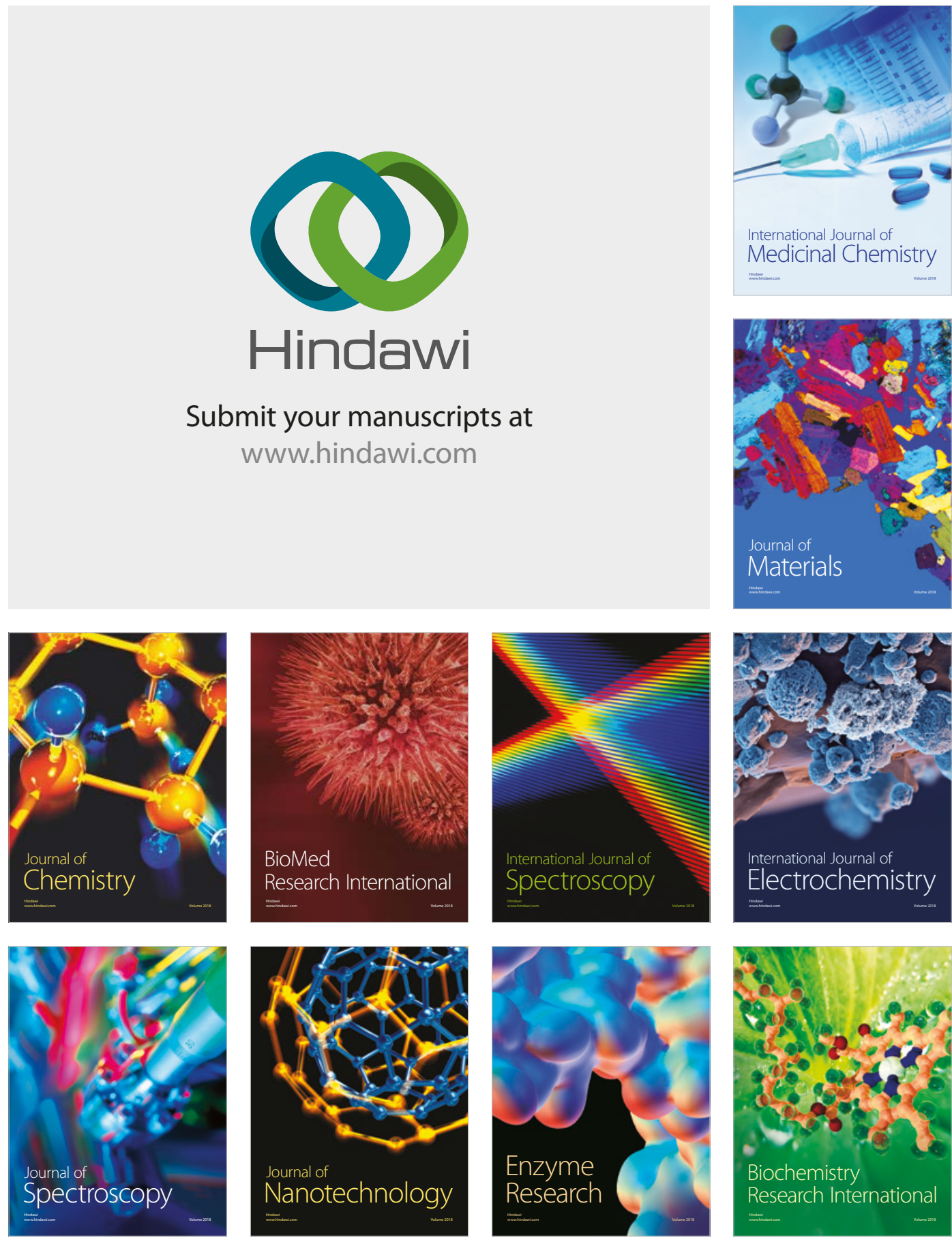
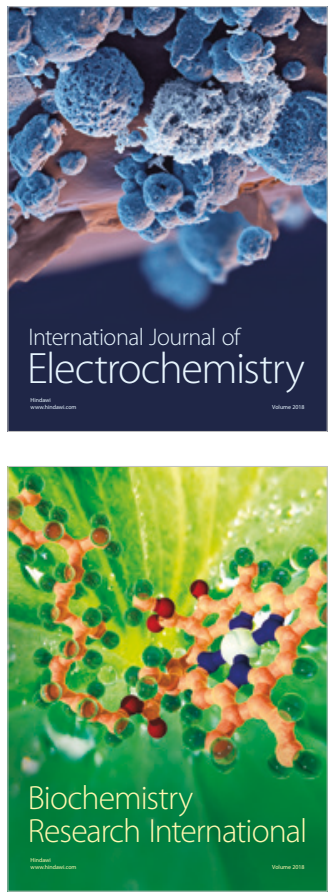